\title{
Anatomy and fructan distribution in vegetative organs of Dimerostemma vestitum (Asteraceae) from the campos rupestres
}

\author{
TAIZA M. SILVA ${ }^{1}$, DIVINA A.A. VILHALVA ${ }^{2 *}$, MOEMY G. MORAES ${ }^{2}$ \\ and RITA DE CÁSSIA L. FIGUEIREDO-RIBEIRO ${ }^{3}$ \\ ${ }^{1}$ Programa de Pós-Graduação em Biodiversidade Vegetal, Instituto de \\ Ciências Biológicas, Universidade Federal de Goiás, Campus Samambaia, \\ Av. Esperança, s/n, 74690-900 Goiânia, GO, Brasil \\ ${ }^{2}$ Instituto de Ciências Biológicas, Universidade Federal de Goiás, Campus \\ Samambaia, Av. Esperança, s/n, 74690-900 Goiânia, GO, Brasil \\ ${ }^{3}$ Núcleo de Pesquisa em Fisiologia e Bioquímica, Instituto de Botânica, \\ Av. Miguel Stéfano, 3687, Água Funda, 04301-902 São Paulo, SP, Brasil
}

Manuscript received on April 28, 2014; accepted for publication on October 24, 2014

\begin{abstract}
Among the compounds stored by plants, several functions are assigned to fructans, such as source of energy and protection against drought and extreme temperatures. In the present study we analyzed the anatomy and distribution of fructans in vegetative organs of Dimerostemma vestitum (Asteraceae), an endemic species from the Brazilian campos rupestres. D. vestitum has amphistomatic and pubescent leaves, with both glandular and non-glandular trichomes. In the basal aerial stem the medulla has two types of parenchyma, which differ from the apical portion. The xylopodium has mixed anatomical origin. Interestingly, although inulin-type fructans with high degree of polymerization were found in all analyzed organs except the leaves, the highest amount and maximum degree of polymerization were detected in the xylopodium. Inulin sphero-crystals were visualized under polarized light in the medulla and in the vascular tissues mainly in the central region of the xylopodium, which has abundant xylem parenchyma. Secretory structures accumulating several compounds but not inulin were identified within all the vegetative organs. The presence of these compounds, in addition to inulin, might be related to the strategies of plants to survive adverse conditions in a semi-arid region, affected seasonally by water restriction and frequently by fire.
\end{abstract}

Key words: Campo rupestre, fructans, inulin spherocrystals, secretory structures, xylopodium.

\section{INTRODUCTION}

Campo rupestre is a vegetation characterized by shrubby-herbaceous species growing on mountains of quartzite and sandstone in the Brazilian states

Correspondence to: Moemy Gomes de Moraes

E-mail: moemy@ufg.br

*Bolsista DCR/CNPq/FAPEG of São Paulo, Rio de Janeiro, Minas Gerais, Bahia and Goiás, predominantly in areas with about 900 m altitude (Neves and Conceição 2010). This Cerrado physiognomy presents a highly diverse and endemic flora with a high number of endangered species (Echternacht et al. 2011). Several adaptive traits are exhibited by such species, which are 
interpreted as strategies to cope with unfavorable environmental factors including low availability of water and nutrients, and fire (Coutinho 2002).

The presence of underground reserve organs is a distinct characteristic of several herbaceous species in the campo rupestre, which provides a rapid sprouting after fire (Neves and Conceição 2010, Hoffmann et al. 2012). In general, underground organs accumulate carbohydrates such as starch, sucrose, oligosaccharides and soluble polysaccharides when the production of photoassimilates exceeds the demand (Pollock 1986). A screening of underground organs of Cerrado plants revealed the occurrence of soluble carbohydrates, starch and proteins in different species and types of underground systems, with soluble carbohydrates being more abundant than starch in several species (Figueiredo-Ribeiro et al. 1986).

Asteraceae is one of the most endemic and abundant families in campo rupestre (Giulietti et al. 1987). The abundance of secretory structures rich in secondary metabolites, in aerial and underground organs is an interesting feature of the Asteraceae, and is possibly related to defense mechanisms against herbivores, pathogenic microorganisms and/or associated with attraction of pollinators (Melo-de-Pinna and Menezes 2002, Vilhalva and Appezzato-da-Glória 2006a, Cury and Appezzatoda-Glória 2009). Glandular trichomes accumulating several secondary substances were reported in both aerial (leaf and bud) and underground reserve organs of two Chrysolaena species (Vernonieae, Asteraceae) from the Cerrado (Appezzato-daGlória et al. 2012). Another marked feature in Asteraceae is the diversity of underground reserve organs, as exemplified by Calea verticillata (Klatt) Pruski, Isostigma megapotamicum (Spreng.) Sherff (Vilhalva and Apezzato-da-Glória 2006b), both presenting xylopodium, and Vernonia grandiflora Less (Hayashi and Apezzato-da-Glória 2007), with tuberous roots and xylopodium. Generally, xylopodia are morphologically complex structures, originated from the radial growth of roots, stems or a mixture of both structures. Therefore, xylopodia are characterized by self-grafting of different stem axes with bud-forming capacity (Appezzato-daGlória et al. 2008a).

Dimerostemma vestitum (Baker) SF Blake is an herbaceous-subshrubby species of the Heliantheae tribe (Asteraceae) with a typical and conspicuous xylopodium. This species is endemic to Brazil and abundant in campos rupestres from Goiás, Distrito Federal and Minas Gerais (Moraes and Semir 2009), but it has not yet been studied with regards to fructan occurrence or the anatomy of the vegetative organs.

Many Asteraceae species accumulate fructans mainly in the vacuole of parenchyma cells of thickened underground organs, where they fulfill the main role of storing carbohydrates. In addition, these compounds are thought to stabilize membranes, to function as osmoregulators (Carvalho et al. 2007, Livingston et al. 2009) and to protect plants against reactive oxygen species (Peshev et al. 2013). Fructans are fructose polymers containing one internal or terminal glucose unit. Inulin-type fructans consist of linear molecules with $\beta$ 2,1 linkages, based on the trisaccharide 1-kestose, occurring mainly in eudicot species, and reaching nearly $80 \%$ of the dry mass in storage organs of temperate (Edelman and Jefford 1968) and subtropical Asteraceae species (Carvalho et al. 2007).

In this work, we studied the anatomy and the location of reserve compounds in the vegetative organs of Dimerostemma vestitum from the campo rupestre and described accumulation of high amounts of inulin in the xylopodium. This feature, in addition to the presence of several secondary compounds in the buds are possibly related to the ecophysiological strategies of the plant to survive adverse conditions in a semi-arid region affected seasonally by water restriction and frequently by fire. 


\section{MATERIALS AND METHODS}

\section{PLANT MATERIAL}

For this study adult individuals of Dimerostemma vestitum were collected in the flowering phase with 7-9 fully developed nodal regions in a preserved area of campo rupestre at the "Reserva Biológica Prof. José Ângelo Rizzo - Serra Dourada" - Mossâmedes, Goiás, Brazil (16 $06^{\prime} 02^{\prime \prime}-16^{\circ} 03^{\prime} 52^{\prime \prime} \mathrm{S}$ and $50^{\circ} 10^{\prime} 59^{\prime \prime}$ - $\left.50^{\circ} 10^{\prime} 12^{\prime \prime} \mathrm{W}\right)$. D. vestitum is a perennial herb or subshrub measuring $1 \mathrm{~m}$, woody at the base, mostly caespitose, from the xylopodium. Leaf blades are chartaceous and tomentose to subtomentose (Moraes and Semir 2009). A voucher specimen (UFG 46597) was deposited in the Herbarium UFG of the Federal University of Goiás (Brazil).

Samples of the aerial parts (fully expanded leaves from the third nodal region and young stems from the first and the basal internodes) and of the underground organs (xylopodium and lateral roots) were selected for structural, histochemical and reserve carbohydrate analyses. The xylopodium was transversely divided into proximal, medium and distal regions for ultrastructural and histochemical analyses and sectioned in central (medullar parenchyma) and peripheral regions (cortex and vascular cylinder) for quantitative and qualitative analyses of reserve carbohydrates.

\section{StRUCTURAL AND UltRASTRUCTURAL ANALYSES}

For light microscopy (LM) analyses, mature leaves, aerial stem internodes, lateral roots, and samples from the proximal, medium and distal regions of the xylopodium of six individuals were collected in the dry and rainy seasons and fixed in FAA 50 (formaldehyde, acetic acid and 50\% ethanol, 1:1:18) (Johansen 1940). Sections made by free hand and with a table microtome were cleared for approximately $15 \mathrm{~min}$ in 4\% sodium hypochlorite, rinsed in distilled water, and double stained with $0.3 \%$ Astra blue and $0.1 \%$ basic fuchsin (Roeser 1972, Kraus et al. 1998). Lateral roots and xylopodium samples were dehydrated in a graded ethanol series, and embedded in Leica Historesin ${ }^{\circledR}$. Serial sections (7-10 $\mu \mathrm{m}$ thick) were cut on a rotary microtome RM 2245 (Leica, Germany), stained with $0.05 \%$ toluidine blue in a Mcllvaine buffer of pH 4.0 (Vidal 1977) and mounted in synthetic resin.

For scanning electron microscopy (SEM) analyses, samples of mature leaves and xylopodia from three plants were fixed in Karnovsky solution (Karnovsky 1965), dehydrated in graded ethanol series and dried to the $\mathrm{CO}_{2}$ critical-point. Following, the samples were mounted on stubs, coated with gold $(30-40 \mathrm{~nm})$ and examined under a JSM-6610 microscope (JEOL, Japan).

Free-hand sections from fixed and fresh material of six individuals were stained for the histochemical tests with Sudan IV (Gerlach 1984) and Steinmetz reagent (Costa 1970) for total lipids; Periodic acid-Schiff's reagent (PAS) for total neutral polysaccharides (McManus 1948); Comassie blue (Fisher 1968) and Xylidine Ponceau reagent (Vidal 1977) for total proteins; Zinc chloride iodine (Kraus and Arduin 1997) and Lugol reagent (Johansen 1940) for starch. Samples were also fixed in Formalinferrous sulfate reagent (Johansen 1940) for the detection of phenolic compounds. In order to identify inulin-type fructans, samples of the xylopodium were sectioned by free-hand and inulin sphero-crystals were visualized under polarized light. The presence of inulin crystals was confirmed by a treatment with Thymol-sulphuric acid reagent (Johansen 1940). Standard control procedures were performed simultaneously. Images were digitally captured with a ICC50 microscope with camera, using the software LAD EZ 1.8.1 version (Leica, Germany).

\section{SOLUBLE CARBohydrate ANALYSES}

For carbohydrate extraction, fresh samples (2 g each) of aerial and underground organs from three individuals collected in the end of the rainy season were boiled in $80 \%$ aqueous ethanol for $3 \mathrm{~min}$, for enzyme denaturation. The mixtures were ground and the homo- 
genate was kept in a water bath at $80^{\circ} \mathrm{C}$ for $15 \mathrm{~min}$. They were then filtered, the residue re-extracted twice and the filtrates combined, constituting the oligosaccharide fraction. The residues were extracted twice in water at $60^{\circ} \mathrm{C}$ for $30 \mathrm{~min}$, vacuum filtered through a cotton tissue and the filtrates were pooled, constituting the water soluble polysaccharide fraction (Carvalho et al. 1998). Free and combined fructose were measured by a ketose-specific modification of the anthrone reaction (Jermyn 1956), using fructose (Sigma) as standard. Samples of fresh material were oven dried at $50^{\circ} \mathrm{C}$ for dry mass determination.

Aliquots of both carbohydrate fractions were purified in columns containing cation (Amberlite IRA 120) and anion exchange resins (Amberlite IRA 410). After purification, the samples were concentrated to dryness under vacuum $\left(37^{\circ} \mathrm{C}\right)$ and re-suspended in ultrapure water $(18.2 \mathrm{M} \Omega)$ to the final concentration of $400 \mu \mathrm{g} \cdot \mathrm{mL}^{-1}$. The samples were analyzed by high performance anion exchange chromatography with pulsed amperometric detection (HPAEC/PAD) using a $4 \times 250 \mathrm{~mm}$ CarboPac PA100 column on a Dionex System ICS 5000 (USA). A gradient was established by mixing eluent A (100 $\mathrm{mM} \mathrm{NaOH})$ with eluent $\mathrm{B}(500 \mathrm{mM}$ sodium acetate in $100 \mathrm{mM} \mathrm{NaOH}$ ) as follows: $0-10 \mathrm{~min}, 5 \mathrm{mM}$; 10-35 min, 5-50 mM; 35-40 min, 50-375 mM; 40$45 \mathrm{~min}, 500 \mathrm{mM}$; 45.1-46 min, $5 \mathrm{mM}$, using a flow rate through the column of $1 \mathrm{~mL} \mathrm{~min}^{-1}$. The applied PAD potentials for E1 (0-0.4 s), E2 (0.41-0.42 s), E3 $(0.43 \mathrm{~s})$ and E4 (0.44-1.00 s) were 0.1, -2.0, 0.6 and -0.1 , respectively. Extracts of tubers of Helianthus tuberosus (Asteraceae) were used as reference for the inulin fructan series (Pollock 1986). All the analyses were performed in triplicate.

\section{RESULTS}

\section{STRUCTURAL ANALYSES}

Mature leaves of Dimerostemma vestitum are amphistomatic. The epidermis is single-layered and covered by cuticle, thicker in the adaxial than in the abaxial surface (Fig. 1A). The anomocytic stomata are located below the level of other epidermal cells, at the adaxial leaf surface (Fig. 1D), contrasting with the abaxial surface, where they are located above the level of the epidermal cells (Fig. 1H, I). Glandular and non-glandular trichomes are extensively distributed throughout the leaf epidermis. The latter is, in general, uniseriate, longer and composed by four cells (Fig. $1 \mathrm{~B}, \mathrm{G})$ or alternatively by three cells, the middle one, similar to an inverted cup, and the apical is thin (Fig. 1E and K). Both cell types accumulate phenolic compounds in the lumen (Table I). Two types of glandular trichomes also occur on both leaf surfaces, one multicellular with a unicellular secretory head curved on the epidermis (Fig. 1E, F) and the other, a pedunculate and biseriate trichome (Fig. 1D, J, K and L). Lipids, proteins and phenols were the main secreted compounds detected in the glandular trichomes (Table I).

The mesophyll is dorsiventral, with one or two layers of overlapping columnar cells of the palisade parenchyma, and a variable number of layers of the spongy parenchyma (Fig. 1A). Lipid droplets occur all over the chlorenchyma. The mesophyll enters partially in the lateral region of the central vein, which has one to three vascular bundles with secretory canals with reduced lumen, surrounded by cortical parenchyma (Fig. 1C).

Both the apical and basal portions of the aerial stem present single-layered epidermis, covered by a thin cuticle and glandular and non-glandular trichomes (Fig. 2A, C, G), similar to those on the leaf blades. The cortex is composed of a maximum of four layers of angular collenchyma, sub epidermal cells accumulating phenolic compounds and starch (Table I), followed by parenchyma and isolated sclereids (Fig. 2E). Fiber bundles are associated with the primary phloem (Fig. 2E, F). Casparian strips are clearly visible in the aerial stem endodermis (Fig. 2F). Secretory canals with dividing epithelium (Fig. 2E, F) accumulate phenolic compounds (Table I) and are widely 

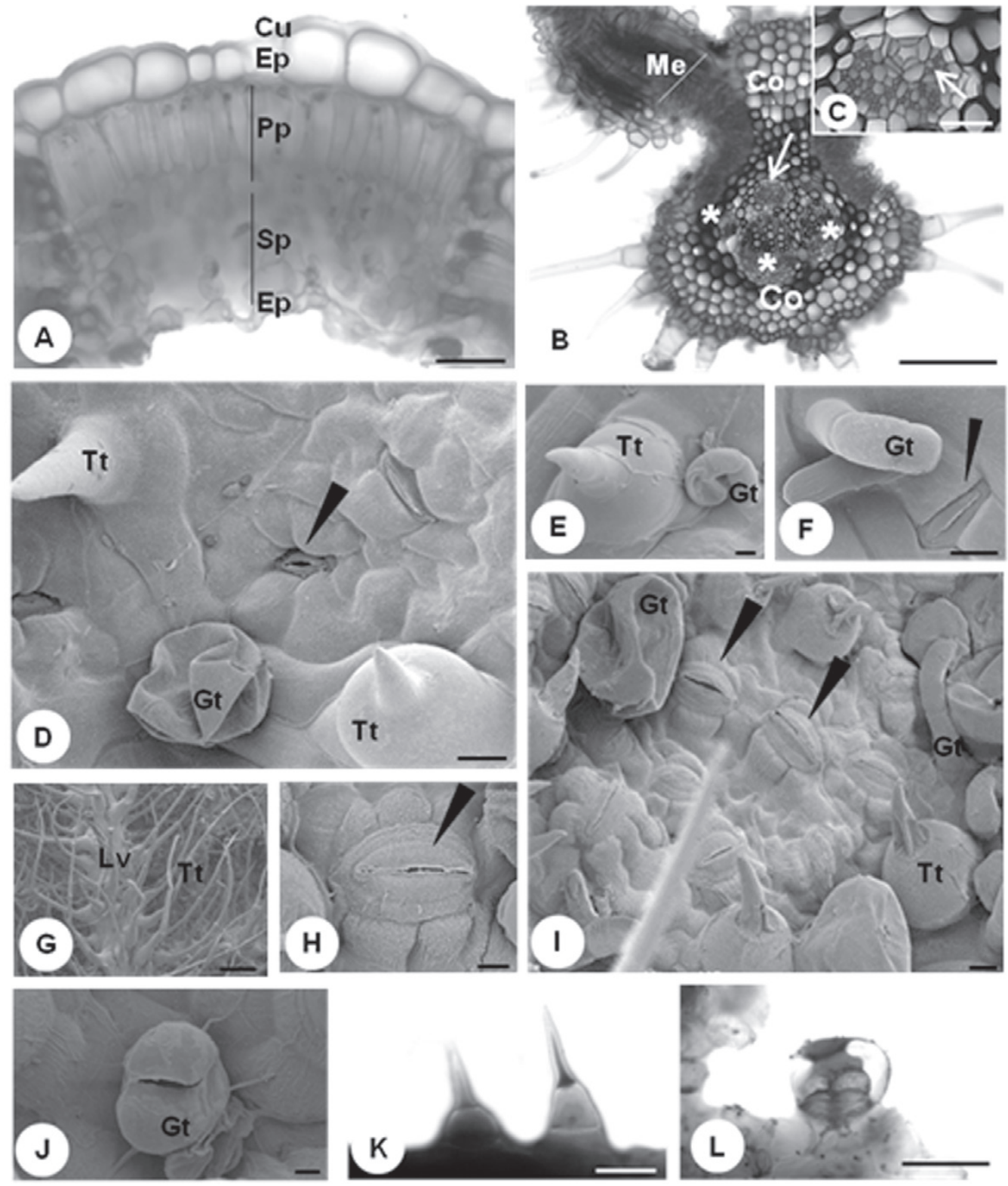

Fig. 1 - Mature leaf of Dimerostemma vestitum. (A) leaf mesophyll evidencing the palisade parenchyma $(\mathrm{Pp})$, spongy parenchyma $(\mathrm{Sp})$ and a cuticle layer $(\mathrm{Cu})$ on the external periclinal wall of epidermal cells (Ep); (B) leaf vein, showing the mesophyll (Me) partly entering in the main vein and vascular bundles (*) surrounded by cortex with lignified cell walls and parenchyma cells in lignification process (Co). (C) Detail of the secretory canals associated with the vascular bundle in the central vein (arrow). (D-J) Scanning electron microscopy of the leaf. (D-F) Adaxial epidermis showing trichomes, non-glandular (Tt) and glandular (Gt), and stomata (arrow heads) in depressions at the epidermis; (G$\mathrm{J})$ Abaxial epidermis showing the presence of non-glandular trichomes ( $\mathrm{Tt}$ ) on main leaf vein $(\mathrm{Lv})$, glandular trichomes (Gt) and stomata (arrow head) above the level of other epidermal cells. (K-L) Histochemical analysis of the leaf. Phenolic compounds in non-glandular trichomes evidenced by ferric chloride $(\mathrm{K})$; glandular trichome evidencing the presence of lipophilic substances by the Sudam IV reagent (L). Scale bars: $100 \mu \mathrm{m}(\mathrm{A}, \mathrm{J}, \mathrm{K}, \mathrm{L}) ; 500 \mu \mathrm{m}$ (B); $60 \mu \mathrm{m}$ (C); $20 \mu \mathrm{m}$ (D, E); $10 \mu \mathrm{m}(\mathrm{F})$; $200 \mu \mathrm{m}(\mathrm{G}) ; 5 \mu \mathrm{m}(\mathrm{H}) ; 160 \mu \mathrm{m}(\mathrm{I})$. 
TABLE I

Distribution of metabolites on different aerial and underground organs of Dimerostemma vestitum detected by histochemical reagents.

\begin{tabular}{|c|c|c|}
\hline Organ & Reagent (compound) & Result \\
\hline \multirow{6}{*}{ Leaf } & Ferric chloride $(\mathrm{Ph})$ & + non-glandular and glandular trichome \\
\hline & Sudan IV (L) & + glandular trichome and cuticle \\
\hline & Steinmetz (L) & + glandular trichome and cuticle \\
\hline & Lugol (St) & - \\
\hline & Iodized zinc chloride $(\mathrm{Ph})$ & + glandular trichome \\
\hline & Coomassie Blue $(\mathrm{P})$ & + glandular trichome \\
\hline \multirow{6}{*}{ Stem } & Ferric chloride $(\mathrm{Ph})$ & $\begin{array}{l}+ \text { secretory canal, glandular trichome and } \\
\text { subepidermal cells }\end{array}$ \\
\hline & Sudan IV (L) & + glandular trichome and cuticle \\
\hline & Steinmetz (L) & + glandular trichome, cuticle and secretory canal \\
\hline & Lugol (St) & + subepidermal cells \\
\hline & Iodized zinc chloride $(\mathrm{Ph})$ & - \\
\hline & Xylidine Ponceau $(\mathrm{P})$ & - \\
\hline \multirow{5}{*}{ Xylopodium } & Lugol (St) & - \\
\hline & Steinmetz (L) & - \\
\hline & Xylidine Ponceau (P) & + buds \\
\hline & Periodic Acid-Schiff -PAS (Pol) & $\begin{array}{l}\text { + xylem parenchyma } \\
+ \text { medullar parenchyma }\end{array}$ \\
\hline & Thymol (In) & + parenchyma \\
\hline \multirow{3}{*}{ Lateral root } & Lugol (St) & - \\
\hline & Steinmetz (L) & - \\
\hline & Xylidine Ponceau (P) & - \\
\hline
\end{tabular}

$\mathrm{Ph}=$ phenolic compounds $; \mathrm{L}=$ lipids $; \mathrm{St}=$ starch $\mathrm{P}=$ proteins $; \mathrm{Pol}=$ polysaccharides $; \mathrm{I}=$ inulin $;+$ positive reaction; - negative reaction.

distributed in the cortex (Fig. 2F). The vascular cylinder consists of collateral bundles in the apical portion of the aerial stem (Fig. 2B) while in the basal portion the vascular cambium begins to differentiate from the secondary vascular tissues (Fig. 2C, D, G). The medulla is also distinct in the apical and basal portions of the stem: in the apical portion it is composed of a homogeneous parenchyma (Fig. $2 \mathrm{~A}$ ), whereas in the basal portion it is heterogeneous, presenting a central parenchyma with thick-walled cells surrounded by larger, thin-walled cells (Fig. 2C, G, H). The latter divide periclinally, forming radial layers (Fig. 2C, G, H).

The thickened underground system of $D$. vestitum consists of an extremely tuberized xylopodium, with the distal region oriented vertically in relation to the soil surface, about $5 \mathrm{~cm}$ deep and with several buds in the upper region, near the soil level (Fig. 3A). The buds originate from the cambium (Fig. 3B) and are covered by cataphylls with phenolic compounds evidenced by the blue-green color developed with toluidine blue staining.

The proximal portion of the xylopodium is covered by the periderm, with a reduced cortex (Fig. 3C, D). This portion is constituted predominantly by secondary xylem, with parenchyma rays intercalated with vessel elements and fibers. The medulla is composed of parenchyma and sclerified cells. The primary xylem presents centrifugal maturation (Fig. 3D), which defines the stem nature of the proximal region of the xylopodium. In the median portion of the xylopodium there are bands of radial parenchyma intercalated with fibers and vessel elements (Fig. 3F). Cambial cells and a reduced amount of phloem were observed towards the outer side of the structure (Fig. 3E). 

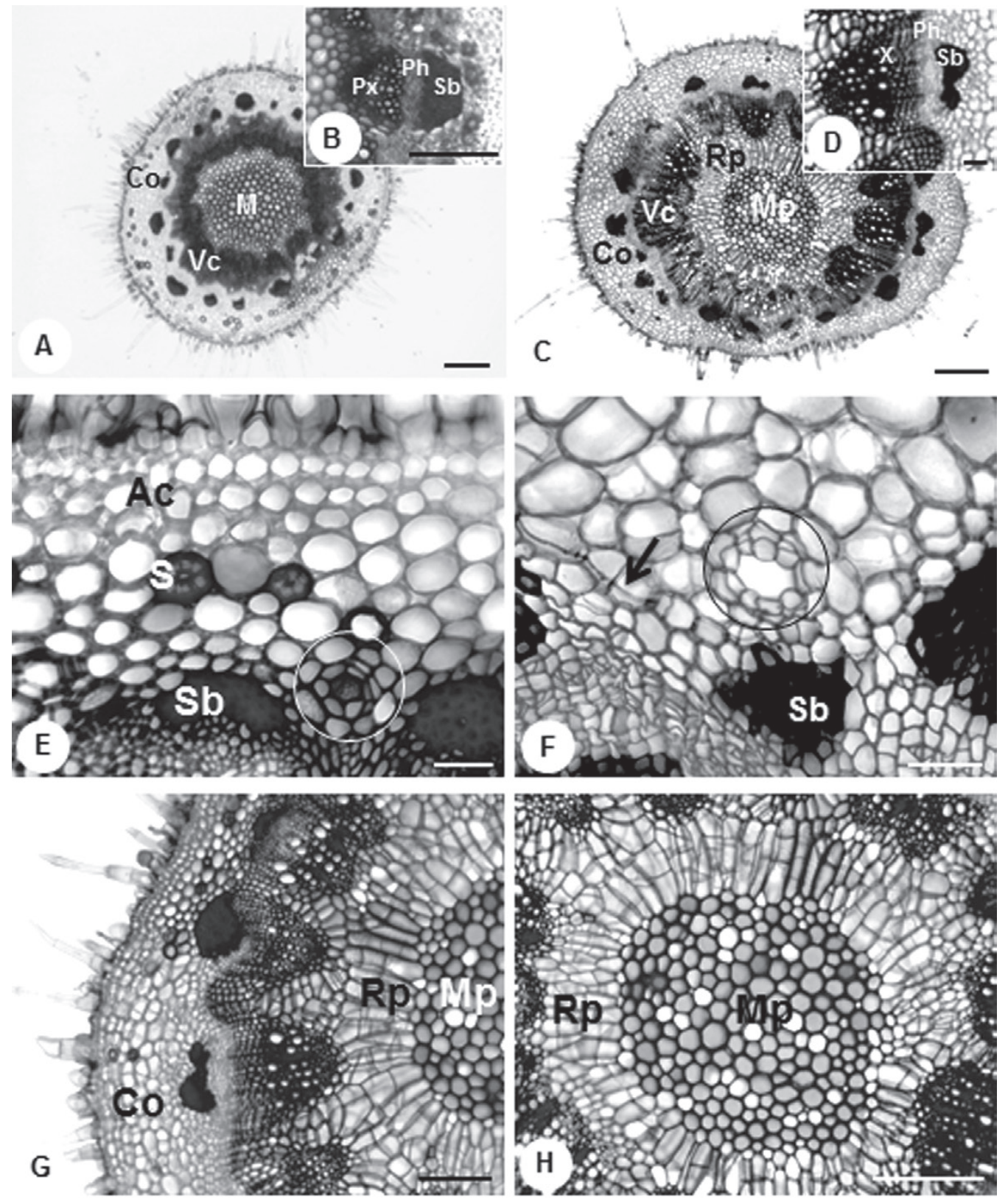

Fig. 2 - Aerial stem of Dimerostemma vestitum. (A, B) Transversal sections of the apical portion (A) highlighting cell wall thickening in the medullar region (M), vascular cylinder (Vc) and cortex (Co). Details of the collateral vascular bundle (B) with primary xylem (Px), phloem (Ph) and sclerenchyma bundles (Sb); (C, D) Basal portion of the aerial stem. General view (C) highlighting medullar parenchyma (Mp), radially arranged cells (Rp), vascular cylinder (Vc) and cortex (Co). Detail of the vascular cylinder (D) showing the formation of the vascular cambium and xylem $(\mathrm{X})$, phloem $(\mathrm{Ph})$ and sclerencyma bundle $(\mathrm{Sb})$. (E) Detail of angular collenchyma (Ac) layers beneath the epidermis, isolated sclereids (S), sclerenchyma bundles ( $\mathrm{Sb}$ ) and secretory canal (circle); (F) Formation of a secretory canal (circle) and evidence of endodermis with Casparian strips (arrow) and sclerencyma bundles (Sb). (G) Stem in the basal portion, showing detail of the vascular cylinder, cortical (Co) and medullar region ( $\mathrm{Rp}, \mathrm{Mp})$. $(\mathrm{H})$ Distinction of the medullar parenchyma $(\mathrm{Mp})$ in a central region and another peripheral, with radially arranged cells (Rp). Scale bars: $1000 \mu \mathrm{m}(\mathrm{A}$, C); $100 \mu \mathrm{m}(\mathrm{B}, \mathrm{E}, \mathrm{F}) ; 200 \mu \mathrm{m}(\mathrm{D}) ; 500 \mu \mathrm{m}(\mathrm{G}, \mathrm{H})$. 


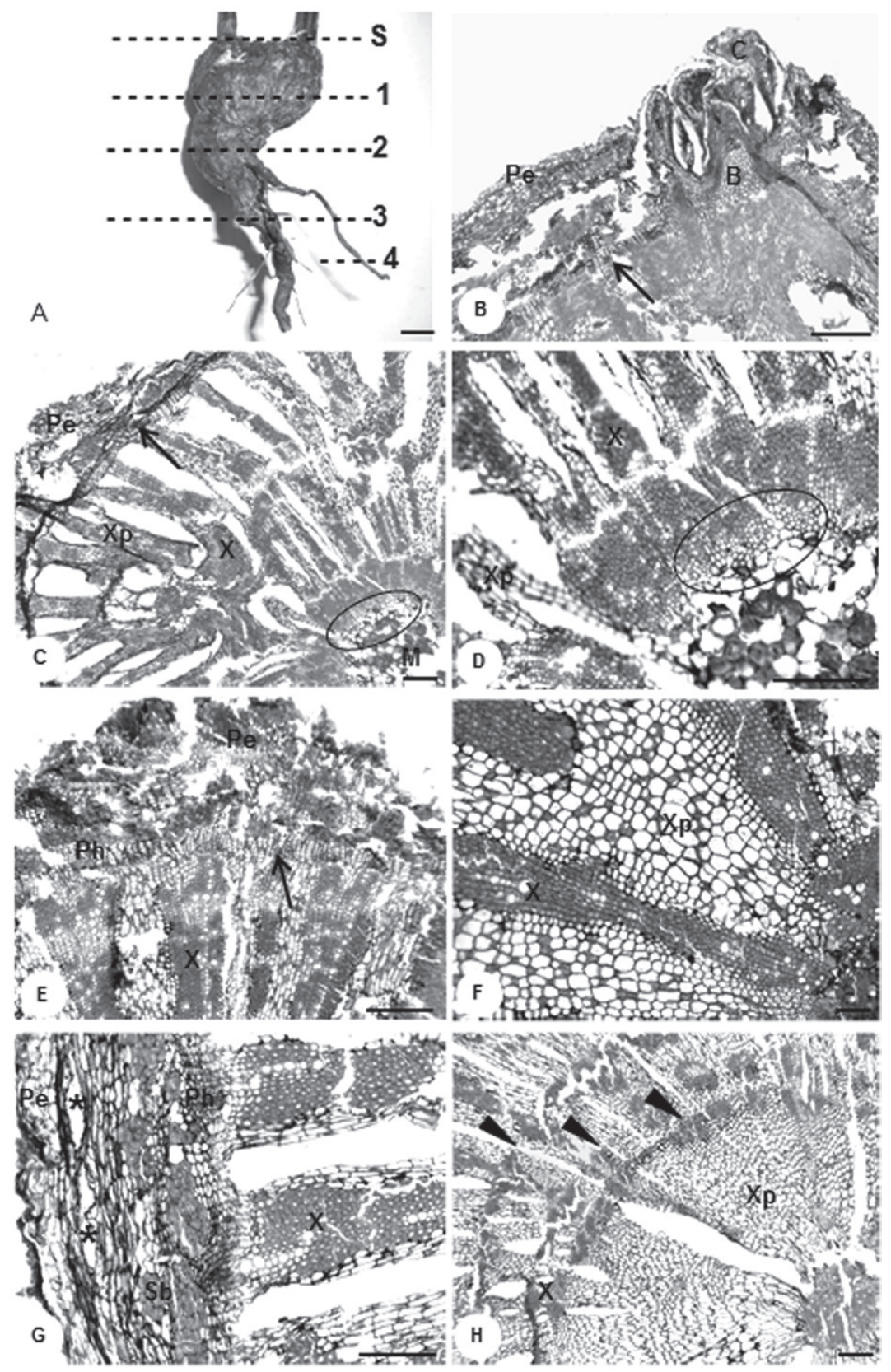

Fig. 3 - Underground organs of Dimerostemma vestitum indicating the analyzed portions (A): Soil level (S); Proximal region (1); Median region (2); Distal region (3); Lateral root (4). Longitudinal sections of the buds of the xylopodium of $D$. vestitum stained with toluidine blue (B). Arrow heads indicate the vascular cambium; cataphyll (C); bud (B); periderm (Pe). (C-H) Transversal sections of the xylopodium. (C-D) Proximal region, detailing the centrifugal maturation (circle) of primary xylem (D). (E-F) Median region of xylopodium showing the formation of periderm, secondary xylem rays and vascular cambium (arrow). (G-H) Distal region of the xylopodium showing $(\mathrm{G})$ periderm $(\mathrm{Pe})$, secretory canals $\left(^{*}\right)$ and fibers associated to phloem $(\mathrm{Sb})$. (H) Growth layers (arrow heads) of secondary xylem (X), xylem parenchyma (Xp) and phloem (Ph). Scale bars: $1 \mathrm{~cm}(\mathrm{~A}) ; 1000 \mu \mathrm{m}$ (B, E); $3000 \mu \mathrm{m}(\mathrm{C}, \mathrm{H}) ; 500 \mu \mathrm{m}(\mathrm{D}, \mathrm{F}, \mathrm{G})$. 
The distal portion of the xylopodium is covered by periderm and the cortex is reduced and composed by irregular and thin-walled parenchyma cells, fiber bundles adjacent to the phloem and secretory canals (Fig. 3G, H). In this portion, xylem predominates, especially the xylem parenchyma. Fibers and vessel elements are inserted between the rays and concentrated in the central region (Fig. $3 \mathrm{H}$ ). The maturation of the primary xylem is centripetal, revealing the root nature of this portion of the xylopodium. Growth layers are clearly observed in this part of the structure (Fig. $3 \mathrm{H}$ ). The lateral roots are small, slender, circular in cross-section, and covered by periderm. The cortex is compact and composed of parenchyma cells, secretory canals with large lumen and fiber bundles adjacent to the phloem. The secondary xylem occupies most of the organ, and consists primarily of fibers, vessel elements dispersed among fibers and only a few parenchyma rays.

Inulin sphero-crystals (Fig. 4E-H, Table I) and inulin globular bodies (Fig. 4A, B) were visualized in the xylopodium, mainly in the reserve parenchyma (Fig. 4G) and in the secondary xylem (Fig. 4C, D). In this tissue, the crystals are located in continuous groups of cells, including the parenchyma rays and vessel elements. The massive presence of inulin in these tissues was confirmed by the visualization of typical sphero-crystals under polarized light and by the positive reaction with specific tests such as thymol and PAS reagents (Fig. 4A-F, Table I).

\section{SOLUBle CARBOHYDRATE ANALYSES}

The central region of the xylopodium had higher amounts of total fructose in both oligoand polysaccharide fractions, followed by the peripheral region. Total fructose content was four times greater in the polysaccharide than in the oligosaccharide fraction of the peripheral region and seven times greater in the central region, reaching about $40 \%$ of the xylopodium dry mass. Conversely, total fructose levels were lower than $1.5 \%$ in lateral roots, aerial stem and leaves, indicating that the xylopodium is in fact the storage organ of $D$. vestitum. The lowest amount of total fructose was observed in the leaves (Table II).

TABLE II

Distribution of total fructose ( $\left.\mathrm{mg} \mathrm{g}^{-1} \mathrm{DM}\right)$ in different vegetative aerial and underground organs of

Dimerostemma vestitum. Values are means $\pm \mathrm{sd}(n=3)$.

\begin{tabular}{lcc}
\hline $\begin{array}{c}\text { Analyzed } \\
\text { organ }\end{array}$ & $\begin{array}{c}\text { Fructo- } \\
\text { Oligosaccharide }\end{array}$ & $\begin{array}{c}\text { Fructo- } \\
\text { Polysaccharide }\end{array}$ \\
\hline Leaf & $9.1 \pm 0.6$ & $4 \pm 0.4$ \\
Stem & $13.6 \pm 5.0$ & $7.2 \pm 3$ \\
Lateral roots & $1.5 \pm 0.2$ & $13.4 \pm 1.4$ \\
$\begin{array}{l}\text { Xylopodium } \\
\text { Peripheral region }\end{array}$ & $27.0 \pm 8.8$ & $113.4 \pm 23.5$ \\
$\begin{array}{l}\text { Xylopodium } \\
\text { Central region }\end{array}$ & $51.0 \pm 12.8$ & $384.4 \pm 92.6$ \\
\hline
\end{tabular}

Qualitative analysis of soluble carbohydrates by HPAEC/PAD (Fig. 5) showed that all analyzed organs of $D$. vestitum, except leaves, presented glucose, fructose, sucrose, 1-kestose, nystose and other components of the inulin homologous series. The main sugars identified in leaves were glucose, fructose and sucrose. Fructose polymers were not detected in any of the fractions of the leaves (Fig. 5A, B).

Fructans of the inulin series were found in aerial stems, mainly in the polysaccharide fraction (Fig. 5C, D), with higher proportion of larger fructans. The low-DP fructan peaks were proportionally lower than in the oligosaccharide fraction of the other organs of D. vestitum (Fig. 5E, G, I). The typical profile of the inulin homologous series was found in the underground organs, but mainly in the xylopodium. Fructans with DP higher than 50 were found in the polysaccharide fractions of the lateral roots and of the peripheral and central regions of the xylopodium (Fig. 5F, H, J).

\section{DISCUSSION}

Dimmerostemma vestitum is a herbaceous Asteraceae species well fitted in campos rupestres. This is probably due to the presence of several features in 

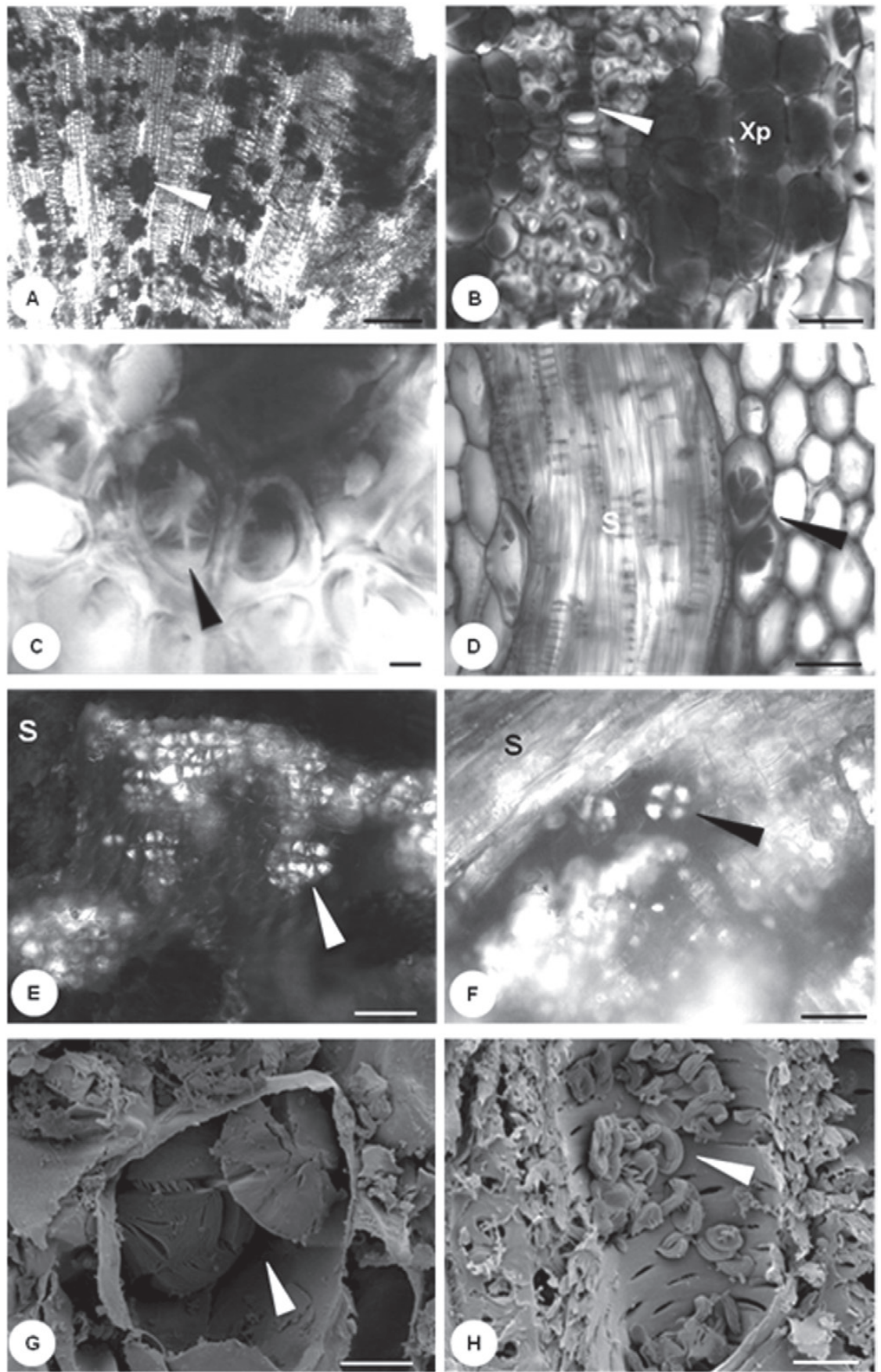

Fig. 4 - Transversal (A-D) and longitudinal sections (E, F) of the distal portion of the xylopodium of Dimerostemma vestitum. (A) Overview of xylopodium showing positive reaction of fructans to PAS reagent (arrow head); (B) Detail of fructans accumulated in the xylem parenchyma cells (Xp) and vessel elements (arrow head); (C, D) Details of inulin accumulation (arrow heads) inside vessel elements (C) and in the parenchyma cells (D); (E, F) Inulin sphero-crystals viewed under polarized light (arrow heads) in parenchyma cells; (G, H) Scanning electron microscopy of inulin particles (arrow heads) accumulated in the parenchyma cells $(\mathrm{G})$ and in vessel elements $(\mathrm{H})$. Sclereids (S). Scale bars: $1000 \mu \mathrm{m}$ (A); $100 \mu \mathrm{m}$ (B, C, D); $250 \mu \mathrm{m}$ (E, F); $10 \mu \mathrm{m}(\mathrm{G}) ; 5 \mu \mathrm{m}$ (H). 

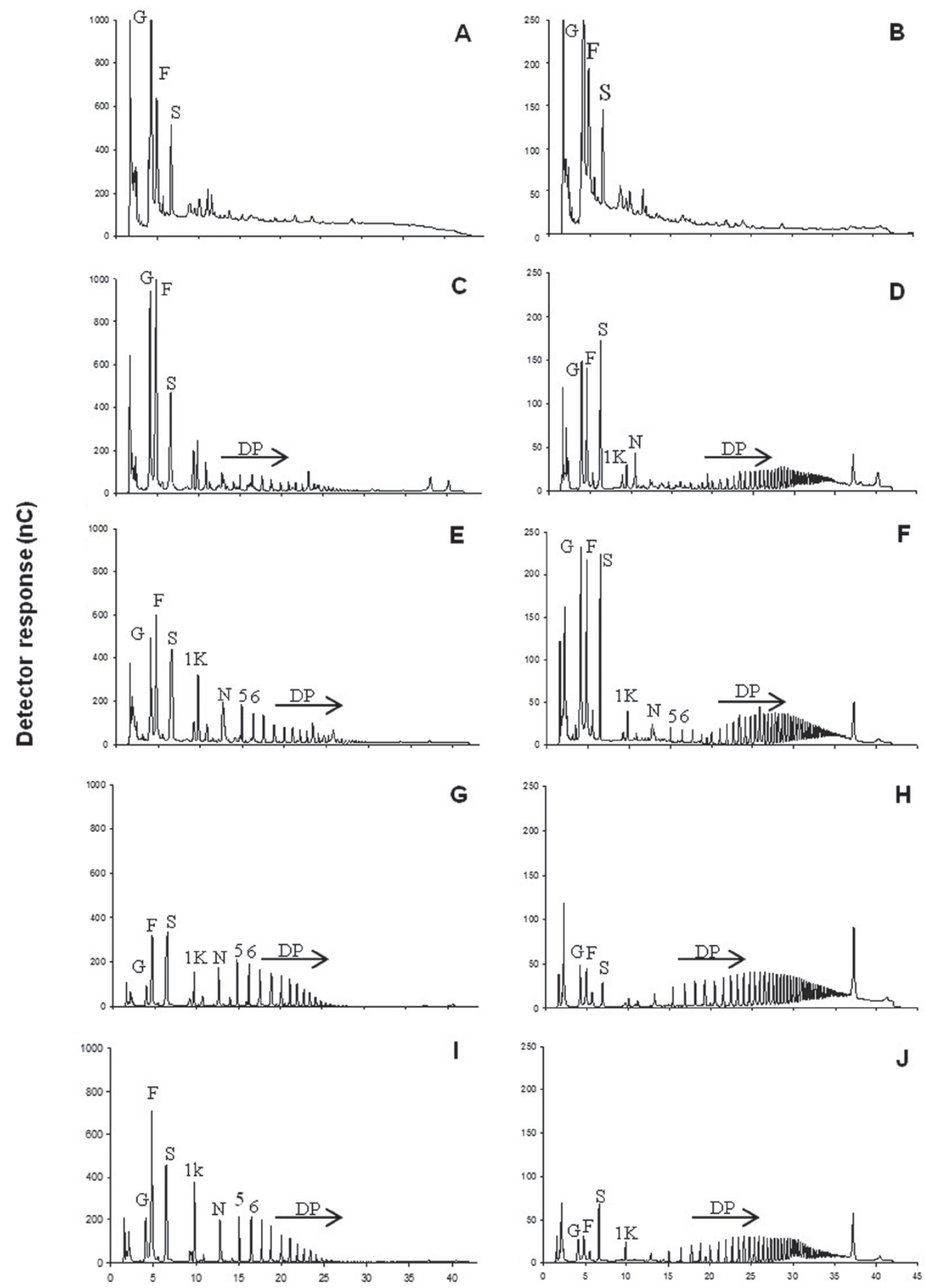

\section{Retention time (min)}

Fig. 5 - HPAEC/PAD profiles of soluble neutral carbohydrates of vegetative aerial and underground organs of Dimerostemma vestitum. Oligosaccharide (A, C, E, G, I) and polysaccharide (B, D, F, H, J) fractions of leaves (A, B); Stem (C, D); Lateral roots (E, F); Xylopodium: Peripheral $(\mathrm{G}, \mathrm{H})$ and central $(\mathrm{I}, \mathrm{J})$ regions.Fructose (F);Glucose (G);Sucrose (S); 1-Kestose (1K); Nystose $(\mathrm{N})$; Arrows indicate the increase in degree of polimerization (DP). 
their shoots and underground organs that allow its resilience over seasonal drought and fire occurrence, environmental constraints typically found in rupestrian environments (Gomes et al. 2014).

One prominent feature of $D$. vestitum leaves is the pubescence, a structural property that influences reflectance and contributes to temperature reduction in leaves, especially in plants from arid and warm environments (Press 1999). Pubescence in $D$. vestitum leaves is constituted by a combination of non-glandular trichomes with phenolic compounds and glandular trichomes rich in phenols and lipids. This association may result, in addition to the physical barrier, in protection against biotic factors, since the chemical composition of pubescent surfaces may limit the attack of pathogens and herbivores (Dalin et al. 2008, Fernández et al. 2011). The genus Dimerostemma, including D. vestitum is characterized by the presence of sesquiterpene lactones of the eudesmanolide type (Stefani et al. 2003). These compounds have been considered as chemotaxonomic markers for this genus and some of them showed ecological and biological functions like anti-herbivore and anti-inflammatory activities (Stefani et al. 2006).

Secretory canals are a common feature in underground organs of Asteraceae species and can be found in Pterocaulon angustifolium (Appezzato-daGlória et al. 2008b), Calea verticillata and Isostigma megapotamicum (Vilhalva and Appezzato-daGlória 2006b). Several studies have described such structures (Melo-de-Pinna and Menezes 2003, Hayashi and Appezzato-da-Glória 2005, Vilhalva and Appezzato-da-Glória 2006a), whose secretions are thought to contribute to overcome biotic and abiotic pressures. However, their actual ecological functions remain to be elucidated.

Leaves of $D$. vestitum are amphistomatic, a relatively common feature in Asteraceae species (Budel et al. 2004, Milan et al. 2006, Dutra et al. 2010). The occurrence of stomata in both sides of leaf surface shortens the distance to $\mathrm{CO}_{2}$ diffusion in mesophyll cells (Parkhurst et al. 1988). In D. vestitum this may result in the improvement of $\mathrm{CO}_{2}$ conductance in mesophyll intercellular air spaces, a major limiting factor for photosynthesis (Parkhurst et al. 1988, Terashima et al. 2005). With efficient photosynthesis, the produced photoassimilates exceeding the demand for maintenance and aerial growth are exported from the source organs and stored in specialized sites (Pollock 1986), such as the underground organs of $D$. vestitum.

Although several herbaceous species from the Cerrado bear thickened underground organs (Filgueiras 2002), the shallow soils and rocky outcrops of the campo rupestre may impose barriers for the development of deep root systems. This occurs in $D$. vestitum that presents thin and suberized lateral roots and the xylopodium located superficially in the soil. Xylopodia are considered adaptive characteristics that help plants to overcome environmental constraints, such as seasonal drought and fire, due to the prominent presence of buds in the upper portion of the organ, with the potential of vigorous sprouting when in appropriate conditions, (Ratter et al. 1997, Hoffmann et al. 2012). The buds of the xylopodium of $D$. vestitum have cambial origin, as in other herbaceous species from the Cerrado (Appezzato-da-Glória and Estelita 2000, Appezzato-da-Glória and Cury 2011). Indeed, the development of the xylopodium in $D$. vestitum is thought to be subject to seasonal control, since in the present work, growth layers were clearly observed in this structure, similarly to what has been reported for Mandevilla species from the Cerrado (Appezzato-da-Glória and Estelita 2000).

Abundance of lignified cells is determinant of xylopodia hardiness, however, even with this rigid structure, the presence of buds in $D$. vestitum allows the plants to resprout, driven by the available resources (Clarke et al. 2013), especially nonstructural carbohydrates stored in the central region of the xylopodium. In other herbaceous species the xylopodia are associated to other storage organs 
such as tuberous roots (Isejima and FigueiredoRibeiro 1993, Appezzato-da-Glória and Estelita 2000, Hayashi and Appezzato-da-Glória 2007). However, this is not the case of $D$. vestitum, whose roots are thin and lignified, and produce fructans in low levels similar to the aerial stems. Therefore, contrasting to other Asteraceae, the xylopodium of $D$. vestitum is indeed the perennial reserve organ of this species, thus fulfilling the storage function of readily usable soluble carbohydrates. Additionally, this organ acts as a continuous source of buds, and store important classes of secondary metabolites in the epidermal glandular trichomes, with putative protective functions against biotic and abiotic environmental constraints, as reported for other Dimerostemma species (Stefani et al. 2003, 2006).

Fructans can be found in aerial organs, such as stems, leaves, flowers, fruits and seeds (Muir et al. 2007). Although fructans of the inulin series have been detected in the aerial stems of $D$. vestitum, the low amounts found, indicate they may play another role besides storage, possibly contributing to the protection of cell membranes and to osmotic adjustment under conditions of water restriction, as already emphasized. In this species fructans are stored mainly in the parenchyma of the central portion of the xylopodium and in the peripheral region of the organ. Thus the predominance of parenchyma cells in the core region of the xylopodium, enabling storage of high amounts of inulin, is consistent with the accumulation of these soluble carbohydrates in the vacuoles of living cells (Darwen and John 1989). Although most plants store sucrose and starch in the reserve organs, the latter has not been identified in $D$. vestitum, which highlights the importance of fructan accumulation in the adaptation of species from environments such as the campos rupestres (Vilhalva et al. 2011).

The predominance of fructans in underground organs of several species of the Cerrado, primarily in the Asteraceae, has been extensively reported, as this family is widely distributed and diversified in this biome (Figueiredo-Ribeiro et al. 1986, Carvalho and Dietrich 1993, Figueiredo-Ribeiro 1993, Isejima and Figueiredo-Ribeiro 1993, Tertuliano and Figueiredo-Ribeiro 1993, Hayashi and Appezzatoda-Glória 2005, 2007, Vilhalva and Appezzato-daGlória 2006a, b, Vilhalva et al. 2011). Contrasting with other Asteraceae species containing inulin with average DP 30, D. vestitum presents a much higher polymer, since DP higher than 50 was detected in the central portion of the xylopodium of plants in the flowering phase. Considering that these polymers are generally hydrolyzed and mobilized during periods of high energetic demands, such as the reproductive phase, it can be expected that higher DP inulin can be found in other phenological phases, such as that reported for Viguiera discolor (Isejima and Figueiredo-Ribeiro 1993), another Heliantheae from the Cerrado. From a utilitarian point of view, considering that high DP inulin is degraded more slowly in the gut, thus contributing to prevent cancer in the distal part of the colon (Roberfroid et al. 1998), the presence of high DP inulin in the xylopodium of $D$. vestitum increases the importance of studies with such endemic species from the campos rupestres.

Although vacuoles are the major site of fructan storage, evidences of the presence of those carbohydrates have been reported in the apoplast (Livingston and Henson 1998, Van den Ende et al. 2005) and in various tissues, including xylem, phloem and parenchyma cells (Vieira and Figueiredo-Ribeiro 1993, Wang and Nobel 1998). In Asteraceae, inulin crystals were found in the medulla and xylem parenchyma in $70 \%$ of the species analyzed in a restricted cerrado area (Tertuliano and Figueiredo-Ribeiro 1993), in the cortical parenchyma of C. chlorolepis tuberous roots (Vilhalva et al. 2011) and in the rhizophores of $V$. herbacea and $V$. platensis (Hayashi and Appezzato-da-Gloria 2005). Inulin sphero-crystals were also distributed in the parenchyma cells of secondary vascular tissue in the xylopodium of D. vestitum. The location of fructans in vascular 
tissues as already documented for other species (Vieira and Figueiredo-Ribeiro 1993), the rapid polymerization and depolymerization process of such polysaccharides (Pollock 1986) and their adherence to cell walls, as in C. chlorolepis (Vilhalva et al. 2011) provide evidences that fructans may play important roles in the adaptation of species to campos rupestres, as it has been proposed for other Cerrado physiognomies with fire occurrence (Gomes et al. 2014) and unfavorable conditions of soil, water and temperature (Dias-Tagliacozzo et al. 1999, Portes et al. 2008).

In conclusion, the uncommon storage of fructans in the hard and lignified xylopodium of $D$. vestitum and the presence of other adaptive structural traits of the aerial stems and leaves highlighted in this study, demonstrates the significance of these features to the success of herbaceous species in potentially stressful environments, such as the campos rupestres.

\section{ACKNOWLEDGMENTS}

This study was partially supported by the Programa Nacional de Apoio ao Desenvolvimento da Botânica (PNADB)/Coodenação de Aperfeiçoamento de Pessoal de Nível Superior (CAPES) and by the Conselho Nacional de Desenvolvimento Científico e Tecnológico (CNPq) (Proc. 312.965/2009-5). The authors are grateful to Dr AM Teles for the taxonomic identification and collection of plant material. TM Silva thanks CAPES for a master's fellowship and DAA Vilhalva for the DCR/CNPq/ FAPEG fellowship. RCL Figueiredo-Ribeiro thanks $\mathrm{CNPq}$ for the research fellowship. The authors also wish to thank Dr MAM Carvalho for helpful advice and for the critical review of the manuscript.

\section{RESUMO}

Entre os compostos armazenados pelas plantas, várias funções são atribuídas aos frutanos, tais como fonte de energia e proteção contra seca e temperaturas extremas. No presente estudo nós analisamos a anatomia e a distribuição de frutanos nos órgãos vegetativos de
Dimerostemma vestitum (Asteraceae), uma espécie endêmica dos campos rupestres brasileiros. $D$. vestitum tem folhas anfiestomáticas e pubescentes, com tricomas glandulares e tectores. A medula do caule aéreo basal tem dois tipos de parênquima, o que difere da porção apical. O xilopódio possui origem anatômica mista. Apesar de terem sido encontrados frutanos da série da inulina com alto grau de polimerização em todos os órgãos analisados, exceto nas folhas, curiosamente, a quantidade mais elevada e o máximo grau de polimerização foram detectados no xilopódio. Esferocristais de inulina foram visualizados sob luz polarizada na medula e nos tecidos vasculares, principalmente na região central do xilopódio, que possui abundante parênquima xilemático. Estruturas secretoras, acumulando vários compostos, exceto inulina, foram identificadas em todos os órgãos vegetativos. A presença desses compostos, em adição à de inulina, pode estar relacionada às estratégias das plantas para sobreviverem em condições adversas em uma região semiárida, sazonalmente afetada pela restrição de água e frequentemente pelo fogo.

Palavras-chave: Campo rupestre, frutanos, esferocristais de inulina, estruturas secretoras, xilopódio.

\section{REFERENCES}

Appezzato-da-Glória B, Costa FB, Silva VC, GobBoNeto L, REHDER VLG AND HAYASHI AH. 2012 Glandular trichomes on aerial and underground organs in Chrysolaena species (Vernonieae - Asteraceae): Structure, ultrastructure and chemical composition. Flora 207: 878-887.

APPEZZATO-DA-GlóRIA B AND CURY G. 2011. Morphoanatomical features of underground systems in six Asteraceae species from the Brazilian Cerrado. An Acad Bras Cienc 83: 981-992.

ApPezzato-DA-Glória B, Cury G, SOARes MKM, Rocha R AND HAYASHI AH. 2008a. Underground systems of Asteraceae species from the Brazilian Cerrado. J Torrey Bot Soc 135: 103-113

ApPeZZATO-DA-GlóRIA B AND EsTelitA MEM. 2000. The developmental anatomy of the subterranean system in Mandevilla illustris (Vell.) Woodson and M. velutina (Mart. ex Stadelm.) Woodson (Apocynaceae). Revta Brasil Bot 23: 27-35.

Appezzato-DA-Glória B, Hayashi AH, Cury G, SoARes MKM AND ROCHA R. 2008b. Occurrence of secretory structures in underground systems of seven Asteraceae species. Bot J Linn Soc 157: 789-796. 
Budel JM, Duarte MR, SAntos CAM and Farago PV. 2004. Morfoanatomia foliar e caulinar de Baccharis dracunculifolia DC., Asteraceae. Acta Farm Bon 23: 477-483.

CARvalho MAM, ASEga AF And Figueiredo-Ribeiro RCL. 2007. Fructans in Asteraceae from the Brazilian Cerrado. In: Shiomi N, Benkeblia N and Onodera S (Eds), Recent advances in fructooligosaccharides research, Kerala: Research Signpost, p. 69-91.

CARVAlHo MAM AND Dietrich SMC. 1993. Variation in fructan content in the underground organs of Vernonia herbacea (Vell.) Rusby at different phenological phases. New Phytol 123: 735-740.

CARVAlHo MAM, PINTO MM AND FIgUeIREDO-RIBEIRO RCL. 1998. Inulin production by Vernonia herbacea as influenced by mineral fertilization and time of harvest. Revta Bras Bot 21: 275-280.

Clarke PJ, Lawes MJ, Midgley JJ, Lamont BB, OJedA F, Burrows GE, ENRIGHT NJ AND KNOX KJE. 2013. Resprouting as a key functional trait: how buds, protection and resources drive persistence after fire. New Phytol 197: 19-35.

Costa AF. 1970. Farmacognosia, v. 3, $2^{\text {nd }}$ ed., Lisboa: Fundação Calouste Gulbenkian, 1032 p.

CoutinHo LM. 2002. O bioma cerrado. In: Klein AL (Ed), Eugen Warming e o cerrado brasileiro: um século depois, São Paulo: Ed. UNESP, p. 77-91.

CURY G AND APPEZZATO-DA-GLÓRIA B. 2009. Internal secretory spaces in thickened underground systems of Asteraceae species. Aust J Bot 57: 229-239.

DALin P, Ågren J, BJörkman C, Huttunen P AND KÄRKKÄINEN K. 2008. Leaf trichome formation and plant resistance to herbivory. In: Schaller A (Ed), Induced plant resistance to herbivory, Netherlands: Springer, p. 89-105.

DARWEN CW AND JOHN P. 1989. Localization of the enzymes of fructan metabolism in vacuoles isolated by a mechanical method from tubers of Jerusalem Artichoke (Helianthus tuberosus L.). Plant Physiol 89: 658-663.

Dias-Tagliacozzo GM, Figueiredo-Ribeiro RCL, Carvalho MAM AND DIETRICH SMC. 1999. Fructan variation in the rhizophores of Vernonia herbacea (Vell.) Rusby, as influenced by temperature. Revta Brasil Bot 22: 267273.

Dutra RC, Ferraz SO, PIMENTA DS AND Sousa OV. 2010. Caracterização morfoanatômica das folhas de Eremanthus erythropappus (DC.) MacLeisch, Asteraceae. Rev Bras Farmacogn 20: 818-824.

ECHTERnACHT L, TROVÓ M, OliveIRA CT AND PIRANI JR. 2011. Areas of endemism in the Espinhaço Range in Minas Gerais, Brazil. Flora 206: 782-791.

EDELMAN J AND JEFFORD TG. 1968. The mechanism of fructosan metabolism in higher plants as exemplified in Helianthus tuberosus. New Phytol 67: 517-531.

FERNÁNDEZ V ET AL. 2011. New insights into the properties of pubescent surfaces: peach fruit as a model. Plant Physiol 156: 2098-2108.
FIGUEIREDO-RIBEIRO RCL. 1993. Distribuição, aspectos estruturais e funcionais dos frutanos, com ênfase em plantas herbáceas do cerrado. Rev Bras Fisiol Veg 5: 203-208.

Figueiredo-Ribeiro RCL, Dietrich SMC, Chu EP, CARVALHO MAM, VIEIRA CCJ AND GRAZIANO TT. 1986. Reserve carbohydrates in underground organs of native Brazilian plants. Revta Brasil Bot 9: 159-166.

FILGUEIRAS TS. 2002. Herbaceous plant communities. In: Oliveira PS and Marquis JR (Eds), The Cerrados of Brazil: Ecology and Natural History of a Neotropical Savanna, New York: Columbia University Press, p. 121-139.

FISHER DB. 1968. Protein staining of ribboned epon sections for light microscopy. Histochemistry 16: 92-96.

GERLACH D. 1984. Botanische mikrotechnik, Stuttgart: Georg Thieme Verlag, 311 p.

Giulietti AM, Menezes NL, Pirani JR, Meguro M AND WANDERLEY MGL. 1987. Flora da Serra do Cipó, Minas Gerais: caracterização e lista das espécies. Bol Bot Univ São Paulo 9: 1-151.

Gomes L, MARACAHIPES L, MARIMON BS, REIS SM, Elias F, MARACAHIPES L, MARIMON-JUNIOR BH AND LENZA E. 2014. Post-fire recovery of savanna vegetation from rocky outcrops. Flora 209: 201-208.

HAYASHI AH AND APPEZZATO-DA-GLÓRIA B. 2005. The origin and anatomy of rhizophores in Vernonia herbacea and $V$. platensis (Asteraceae) from the Brazilian Cerrado. Aust $\mathrm{J}$ Bot 53: 273-279.

HAYASHI AH AND APPEZZATO-DA-GLÓRIA B. 2007. Anatomy of the underground system in Vernonia grandiflora Less. and V. brevifolia Less. (Asteraceae). Braz Arch Biol Techn 50: 979-988.

HofFMANN WA, Geiger EL, Gotsch SG, RossatTo DR, SILVA LCR, LAU OL, HARIDASAN M AND Franco AC. 2012. Ecological thresholds at the savanna-forest boundary: how plant traits, resources and fire govern the distribution of tropical biomes. Ecol Lett 15: 759-768.

ISEJIMA EM AND FIGUEIREDO-RIBEIRO RCL. 1993. Fructan variations in tuberous roots of Viguiera discolor Baker (Asteraceae): The influence of phenology. Plant Cell Physiol 34: 723-727.

JERMYN MA. 1956. A new method for the determination of ketohexoses in presence of aldohexoses. Nature 177: 38-39.

JoHANSEN DA. 1940. Plant microtechnique, New York: Mc Graw-Hill, 523 p.

KARNOVSKY MJ. 1965. A formaldehyde-glutaraldehyde fixative of high osmolality for use in electron microscopy. J Cell Biol 27: 137-138.

KRAUS JE AND ARDUIN M. 1997. Manual básico de métodos em morfologia vegetal. Seropédica: EDUR, 198 p.

Kraus JE, Sousa HC, Rezende MH, CAstro NM, VeCCHI C AND LUQUE R. 1998. Astra blue and basic fuchsin double staining of plant materials. Biotech Histochem 73: 235243.

Livingston DP AND HeNSON CA. 1998. Apoplastic sugars, fructans, fructan exohydrolase, and invertase in winter oat: responses to second-phase cold hardening. Plant Physiol 116: 403-408. 
LIVINGSTON DP, HiNCHA DK AND HEYER AG. 2009. Fructan and its relationship to abiotic stress tolerance in plants. Cell Mol Life Sci 66: 2007-2023.

MCMANUS JFA. 1948. Histological and histochemical uses of periodic acid. Stain Technol 23: 99-108.

Melo-DE-PinNA GFA AND MenEZeS NL. 2002. Vegetative organ anatomy of Ianthopappus corymbosus Roque \& Hind (Asteraceae-Mutisieae). Revta Brasil Bot 25: 505514.

Melo-De-Pinna GFA And MenEZes NL. 2003. Meristematic endodermis and secretory structures in adventitious roots of Richterago Kuntze (Mutisieae-Asteraceae). Revta Brasil Bot 26: 1-10.

Milan P, HAYASHI AH AND APPEZZATO-DA-GlóRIA B. 2006 Comparative leaf morphology and anatomy of three Asteraceae species. Braz Arch Biol Techn 49: 135-144.

MorAES MD AND SEMIR J. 2009. A revision of Brazilian Dimerostemma (Asteraceae, Heliantheae, Ecliptinae), with a new species and taxonomic adjustments. Brittonia 61: 341-365.

Muir JG, SHepherd SJ, Rosella O, Rose R, BARRetT JS AND GIBSON PR. 2007. Fructan and free fructose content of common Australian vegetables and fruit. J Agr Food Chem 55: 6619-6627.

NeVES SPS AND CONCEIÇÃO AA. 2010. Campo rupestre recém-queimado na Chapada Diamantina, Bahia, Brasil: plantas de rebrota e sementes, com espécies endêmicas na rocha. Acta Bot Bras 24: 697-707.

PARKHURST DF, WONG SC, FARQUHAR GD AND COWAN IR 1988. Gradients of intercellular $\mathrm{CO}_{2}$ levels across the leaf mesophyll. Plant Physiol 86: 1032-1037.

Peshev D, Vergaumen R, Moglia A, Hideg E and Van DEN ENDE W. 2013. Towards understanding vacuolar antioxidant mechanisms: a role for fructans? J Exp Bot 64: 1025-1038.

PoLLOCK CJ. 1986. Fructans and the metabolism of sucrose in vascular plants. New Phytol 104: 1-24.

Portes MT, FIgUeIREDO-RIBEIRO RCL AND CARVALHO MAM. 2008. Low temperature and defoliation affect fructan metabolizing enzymes in different regions of the rhizophores of Vernonia herbacea. J Plant Physiol 165: 1572-1581

PRESS MC. 1999. The functional significance of leaf structure: a search for generalizations. New Phytol 143: 213-219.

RATTER JA, RiBEIRO JF AND BRIDGEWATTER S. 1997. The Brazilian cerrado vegetation and threats to its biodiversity. Ann Bot 80: 223-230.

RoBERFROID MB, VAN LOO JAE AND GIBSON GR. 1998. The bifidogenic nature of chicory inulin and its hydrolysis products. J Nutr 128: 11-19.
ROESER KR. 1972. Die Nadel der SchwarzkieferMassenprodukt und Kunstwerk der Natur. Mikrokosmos 61: 33-36.

STEFANi R, EBERLIN MN, TOMAZELA DM AND DA COSTA FB 2003. Eudesmanolides from Dimerostemma vestitum. J Nat Prod 66: 401-403.

Stefani R, SCHORR K, TURETA JM, VichNEWSKI W, MERFORT I AND DA COSTA FB. 2006. Sesquiterpene lactones from Dimerostemma species (Asteraceae) and in vitro potential anti-inflammatory activities. Z Naturforsch C 61: 647652.

Terashima I, Araya T, Miyazawa SI, Sone K AND YanO S. 2005. Construction and maintenance of the optimal photosynthetic systems of the leaf, herbaceous plant and tree: an eco-developmental treatise. Ann Bot 95: 507-519.

TERTUliano MF AND FigUEIREDO-RIBEIRO RCL. 1993. Distribution of fructose polymers in herbaceous species of Asteraceae from the Cerrado. New Phytol 123: 741-749.

Van den Ende W, Van Laere A, Le Roy K, Vergauwen R, BOOGAERTS D, FIGUEIREDO-RIBEIRO RCL AND CARVALHO MAM. 2005. Molecular cloning and characterization of a high DP fructan:fructan 1-fructosyltransferase from Viguiera discolor (Asteraceae) and its heterologous expression in Pichia pastoris. Physiol Plantarum 125: 419-429.

VIDAL BC. 1977. Acid glycosaminoglycans and endochondral ossification: micro-espectrophotometric evaluation and macromolecular orientation. Cell Mol Biol 22: 45-64.

VIEIRA CCJ AND FIGUEIREDO-RIBEIRO RCL. 1993. Fructosecontaining carbohydrates in the tuberous root of Gomphrena macrocephala St.-Hil. (Amaranthaceae) at different phenological phases. Plant Cell Env16: 919-928.

VILHALVA DAA AND APPEZZATO-DA-GLÓRIA B. 2006a. Morfoanatomia da raiz tuberosa de Vernonia oxylepis Sch. Bip. in Mart. ex Baker - Asteraceae. Acta Bot Bras 20: 591-598.

Vilhalva DAA AND APPEZZATO-DA-GLÓRIA B. 2006b. Morfoanatomia do sistema subterrâneo de Calea verticillata (Klatt) Pruski e Isostigma megapotamicum (Spreng.) Sherff - Asteraceae. Revta Brasil Bot 29: 39-47.

Vilhalva DAA, Cortelazzo AL, Carvalho MAM AND FigUEIREDO-RIBEIRO RCL. 2011. Histochemistry and ultrastructure of Campuloclinium chlorolepis (Asteraceae) tuberous roots accumulating fructan: evidences of functions other than reserve carbohydrate. Aust J Bot 59: 46-52.

WANG N AND NoBel P. 1998. Phloem transport of fructans in the Crassulacean Acid Metabolism species Agave deserti. Plant Physiol 116: 709-714. 